\title{
Effects of Carbon Tetrachloride on Albumin Synthesis
}

\author{
Marcus A. Rothschild, Murray Oratz, and Sidney S. Schreiber \\ From the Radioisotope Service, New York Veterans Administration Hospital; \\ the Department of Medicine, New York University School of Medicine; and \\ the Department of Biochemistry, New York University College of Dentistry, \\ New York 10010
}

\begin{abstract}
A B S T R A C T The effects of $\mathrm{CCl}_{4}$ on albumin synthesis were studied employing the isolated perfused liver. Carbonate- ${ }^{14} \mathrm{C}$ was used to measure newly synthesized albumin. $2.5 \mathrm{ml}$ of $\mathrm{CCl}_{4}$ was administered by stomach tube $2 \mathrm{hr}$ before perfusion. Albumin synthesis decreased from 36 to $5 \mathrm{mg}$ following the ingestion of $\mathrm{CCl}_{4}$. Preperfusing the livers for $1 \mathrm{hr}$ before measuring albumin synthesis resulted in an increase to $12 \mathrm{mg}$, and the addition of tryptophan to a final concentration of $10 \mathrm{~mm}$ resulted in a further increase to $19 \mathrm{mg}$. Cortisone did not protect against the toxic effects of $\mathrm{CCl}_{4}$ when administered to the donor rabbits. Fasting resulted in an increased sensitivity to $\mathrm{CCl}_{\mathrm{s}}$ and an antioxidant was not effective in protecting against the toxic manifestations of $\mathrm{CCl}_{4}$.
\end{abstract}

\section{INTRODUCTION}

The metabolism of carbon tetrachloride $\left(\mathrm{CCl}_{4}\right)$ yields products that are hepatotoxic and cause fragmentation of the endoplasmic reticulum (1-3) and disruption of ribosomes into subunits (4) with subsequent disengagement of the $40 \mathrm{~S}$ subunit from mRNA. These changes should result in a rapid loss of the ability of the liver to synthesize albumin, since albumin is produced on a polysome bound to the endoplasmic reticulum $(5,6)$. Other conditions such as fasting and exposure to alcohol also alter the integrity of the endoplasmic membrane-bound polysome (7-11) and both feeding and/or exposure to $10 \mathrm{~mm}$ tryptophan have been shown to reverse the acute damage produced in these organelles with restoration of albumin synthesis (11-14).

The present studies were undertaken to determine the effects of $\mathrm{CCl}_{4}$ on albumin synthesis, and to examine the influence of diet, tryptophan, cortisone, and an antioxi-

This study was presented in part at the 84th Meeting of the Association of American Physicians, Atlantic City, N. J., 1971.

Received for publication 10 March 1972 and in revised form 27 April 1972. dant on the toxic effects of $\mathrm{CCl}_{4}$. The results indicate that $\mathrm{CCl}_{4}$ rapidly inhibits albumin production and that the addition of tryptophan does result in some improvement in albumin synthesis.

\section{METHODS}

Protocol. Male rabbits, $1.3-1.5 \mathrm{~kg}$ were used as donors and were fed $80-100 \mathrm{~g}$ of a standard rabbit chow ad lib. until operation. At $2 \mathrm{hr}$ before surgery, the $\mathrm{CCl}_{4}$-treated rabbits received $2.5 \mathrm{ml}$ of $\mathrm{CCl}_{4}$ in mineral oil by stomach tube. The nine experimental groups are indicated in Table I.

These groups were chosen to examine the effects of tryptophan, washout perfusions, cortisone acetate, fasting, and the antioxidant $\mathrm{N}, \mathrm{N}^{\prime}$-diphenyl-p-phenylenediamine (DP$\mathrm{PD})^{1}$ on albumin production (4). In half of the studies in group 4, the livers were perfused for $60 \mathrm{~min}$ before measuring albumin synthesis with carbonate $-{ }^{14} \mathrm{C}$. In the other half, the livers were perfused for $60 \mathrm{~min}$ and then transferred to a fresh identical perfusion system where albumin synthesis was measured. The results were the same whether the perfusion for $1 \mathrm{hr}$ before the measurement was in a separate system or not. Thus the data obtained from both methods were combined. Similar results were obtained in group 5. In groups $6-9$ the livers were perfused for $1 \mathrm{hr}$ before the introduction of the label.

In groups 6 and 7 , cortisone acetate $3 \mathrm{mg} / \mathrm{kg}$ body weight was administered intramuscularly $2 \mathrm{hr}$ before the ingestion of $\mathrm{CCl}_{4}$.

Group 8 was fasted for $48 \mathrm{hr}$ before $\mathrm{CCl}_{4}$ administration. The two rabbits in group 9 and two control rabbits were injected intraperitoneally with $60 \mathrm{mg}$ of DPPD suspended in $1 \%$ gum arabic and Tween $(0.5 \%)$ at 27 and $3 \mathrm{hr}$ before $\mathrm{CCl}_{4}$ administration (4).

Perfusion. $2 \mathrm{hr}$ after $\mathrm{CCl}_{4}$ ingestion, the rabbits were anesthetized with open drop ether and the livers removed and mounted in a humidified chamber for perfusion as previously described (12-15). During surgery, the liver was perfused by an auxilliary perfusion and was deprived of blood for less than $15 \mathrm{sec}$. The composition of this perfusate was the same as the main perfusate.

The perfusate consisted of 2 parts heparinized rabbit blood and 1 part oxygenated Krebs-Henseleit solution containing $400-500 \mu$ moles of amino acids $/ 100 \mathrm{ml}$ including

\footnotetext{
${ }^{1}$ Abbreviation used in this paper: DPPD, N,N'-diphenyl$p$-phenylenediamine.
} 
$25 \mu$ moles arginine, $5 \mu$ moles isoleucine, $69 \mu$ moles L-glutamine. Tryptophan was present at only trace levels (12). Amino acid analyses of the perfusates and the liver were not significantly different from those reported previously (12). Initial glucose levels were between $70-100 \mathrm{mg} / 100$ ml. Rabbit albumin was added to adjust the final albumin level to $3.1-3.4 \mathrm{~g} / 100 \mathrm{ml}$. The oxygenated perfusate was pumped into the portal vein at flow rates of $1.0-1.4 \mathrm{ml} /$ min per $g$ liver.

To label the intracellular arginine and hence the guanido carbon of albumin, $200 \mu \mathrm{Ci}$ of carbonate $-{ }^{14} \mathrm{C}$ (SA $5 \mathrm{mCi} /$ mmole) as carbonate in $0.5 \mathrm{ml}$ of saline was added directly to the portal inflow as a single pulse $(12,13)$. The perfusion was continued for $2.5 \mathrm{hr}$ after this injection and albumin synthesis calculated from the following expression:

$$
\begin{aligned}
\begin{array}{c}
\text { Albumin synthesized } \\
(\mathrm{mg})
\end{array} & =\begin{array}{l}
\text { total perfusate } \\
\text { albumin }(\mathrm{mg})
\end{array} \\
& \times \frac{\text { Albumin Guanido- }{ }^{14} \mathrm{C} \mathrm{SA}}{\text { Synthesized urea- }{ }^{14} \mathrm{C} \mathrm{SA}} .
\end{aligned}
$$

Synthesized urea was calculated from the difference between the initial and final urea content of the perfusate and the volume of distribution within the liver and red cell. The space of distribution of urea in the liver and red cell has been determined to average $60 \%$. Urea- ${ }^{14} \mathrm{C}$ activity was determined at the end of the perfusion and related to the net urea synthesis (15). The specific activity of this urea carbon was assumed to equal the mean specific activity of the precursor guanido carbon of arginine (16-18). The dose of $\mathrm{CO}_{2}{ }^{14} \mathrm{C}$ varied by as much as $50 \%$ and thus the specific activity of the urea carbon and the guanido carbon of albumin varied. For comparison purposes, all the values were normalized to a urea carbon specific activity of $1 \times 10^{5}$.

The concentration of protein in plasma or perfusate was determined with a biuret reagent (19) and protein partition with a Kern microelectrophoresis unit (20).

Albumin was isolated by preparative acrylamide gel electrophoresis, hydrolyzed, and the specific activity of the guanido carbon determined by consecutive treatment with arginase and urease as has been described in detail previously (12-15). Albumin purity was checked by immunoelectrophoresis (21) and the ${ }^{14} \mathrm{C}$ and ammonia $\mathrm{N}$ released by enzyme treatment assayed by the technique of Conway and Byrne (22). DNA was determined by the indole method of Ceriotti as modified by Keck (23) and RNA was determined by the method of Fleck and Begg (24). Total hepatic protein was determined by the method of Lowry (25). The description of the techniques for isolation of the bound polysomes has likewise been detailed previously (13). The method described by Blobel and Potter (26) was used. In these isolations and analyses, rabbit liver cell sap, which has been shown to contain a potent and stable RNase inhibitor, ${ }^{2}$ was employed.

\section{RESULTS}

All rabbits tolerated the mineral oil and the $\mathrm{CCl}_{4}$ without incident except for slight diarrhea.

The data for the nine groups are given in Table II. The weights of the livers from fasted donors, group 8 , were less than controls as expected. However in group 3

\footnotetext{
${ }^{2}$ Oratz, M. Unpublished observations.
}

\begin{tabular}{|c|c|c|c|}
\hline Group & Donor & Perfusate & Remarks \\
\hline 1 & Fed & Control & $\begin{array}{l}\text { Alb. Syn. measured } \\
\text { after } 15 \text { min of perf.* }\end{array}$ \\
\hline 2 & Fed $\mathrm{CCl}_{4}$ & Control & $\begin{array}{l}\text { Alb. Syn. measured } \\
\text { after } 15 \mathrm{~min} \text { of perf.* }\end{array}$ \\
\hline 3 & Fed $\mathrm{CCl}_{4}$ & $10 \mathrm{~mm}$ Trp. & $\begin{array}{l}\text { Alb. Syn. measured } \\
\text { after } 15 \text { min of perf.* }\end{array}$ \\
\hline 4 & Fed $\mathrm{CCl}_{4}$ & $10 \mathrm{~mm}$ Trp. & $\begin{array}{l}\text { Alb. Syn. measured } \\
\text { after } 1 \mathrm{hr} \text { of perf.* }\end{array}$ \\
\hline 5 & Fed $\mathrm{CCl}_{4}$ & Control & $\begin{array}{l}\text { Alb. Syn. measured } \\
\text { after } 1 \mathrm{hr} \text { of perf.* }\end{array}$ \\
\hline 6 & Fed $\mathrm{CCl}_{4}$-Cort $\ddagger$ & Control & $\begin{array}{l}\text { Alb. Syn. measured } \\
\text { after } 1 \mathrm{hr} \text { of perf.* }\end{array}$ \\
\hline 7 & Fed $\mathrm{CCl}_{4}$-Cort $\ddagger$ & $10 \mathrm{~mm}$ Trp. & $\begin{array}{l}\text { Alb. Syn. measured } \\
\text { after } 1 \mathrm{hr} \text { of perf.* }\end{array}$ \\
\hline 8 & Fasted $\mathrm{CCl}_{4}$ & $10 \mathrm{~mm}$ Trp. & $\begin{array}{l}\text { Alb. Syn. measured } \\
\text { after } 1 \mathrm{hr} \text { of perf.* }\end{array}$ \\
\hline 9 & Fed $\mathrm{CCl}_{1}$-DPPD $\$$ & Control & $\begin{array}{l}\text { Alb. Syn. measured } \\
\text { after } 1 \mathrm{hr} \text { of perf.* }\end{array}$ \\
\hline
\end{tabular}

TABLE I

Protocol

* The livers in groups 1-3 were perfused for 15 min before the addition of the carbonate-14 $\mathrm{C}$. All other livers were perfused for $1 \mathrm{hr}$ before the addition of the label.

‡ Cortisone acetate $3 \mathrm{mg} / \mathrm{kg} 2 \mathrm{hr}$ before $\mathrm{CCl}_{4}$.

$\S \mathrm{DPPD}=\mathrm{N}, \mathrm{N}^{\prime}$-diphenyl- $p$-phenylenediamine.

and 6 the donor livers were also smaller without obvious explanation.

Urea synthesis averaged $80 \pm 12 \mathrm{mg} / 100 \mathrm{~g}$ wet liver weight during the $2.5 \mathrm{hr}$ of perfusion. In the other groups there was a slight decrease in the absolute amount of urea synthesized. Synthesis of urea was measured at 15-30-min intervals during the perfusion and only those studies which showed a steady urea production were used. A basic assumption in the determination of the synthesis of albumin using carbonate $-{ }^{14} \mathrm{C}$ is that the fractional rates of urea and albumin synthesis remain constant during the study period. Within $15 \mathrm{~min}$ after the label has been given, $95 \%$ of the labeled products, urea and albumin, have been synthesized. Subsequent alterations in unlabeled albumin production would have little effect on the specific activity of the albumin because of the large circulating mass of albumin. This is not so with urea. Since the perfusate is recirculated there is some persistance of the $\mathrm{CO}_{2-}{ }^{14} \mathrm{C}$ and labeling of urea continues for a finite period. Thus it is not truly a pulse label. This additional label, coming from a very low specific activity carbonate contributes very little additional activity. However if the continued production of unlabeled urea varies during the study period, then there would be marked alterations of synthesized urea specific activity and calculated yalues for albumin synthesis would be inaccurate. Setting the total urea production as $100 \%$ for the $150 \mathrm{~min}$ perfusion period, the fractional rate of urea production in the animals was measured at 15-30min intervals. The average values were $14 \pm 2 \%$ at 15 
TABLE II

Albumin Synthesis

\begin{tabular}{|c|c|c|c|c|c|c|c|c|c|c|}
\hline \multirow{2}{*}{\multicolumn{2}{|c|}{ Group }} & B & C & $\mathrm{D}$ & $\mathrm{E}$ & $\mathbf{F}$ & G & $\mathrm{H}$ & I & $\mathbf{J}$ \\
\hline & & $\begin{array}{l}\text { Liver } \\
\text { weight }\end{array}$ & $\begin{array}{c}\text { Urea } \\
\text { synthesis }\end{array}$ & $\begin{array}{l}\text { Urea C } \\
\text { SA }\end{array}$ & $\begin{array}{l}\text { Perfusate } \\
\text { circulating } \\
\text { albumin }\end{array}$ & $\begin{array}{c}\text { Albumin } \\
\text { Guanido C } \\
\text { SA }\end{array}$ & $\begin{array}{l}\text { Albumin } \\
\text { synthesis }\end{array}$ & RNA/DNA & $\begin{array}{l}\text { Protein/ } \\
\text { DNA }\end{array}$ & Remarks \\
\hline & & $g$ & $\begin{array}{l}m g / 100 \mathrm{~g} \\
2.5 \mathrm{hr}\end{array}$ & $\begin{array}{l}C T S / m g C \\
\times 10^{-5}\end{array}$ & $m g$ & $C T S / m g C$ & $\begin{array}{c}m g / 100 \mathrm{~g} \\
2.5 \mathrm{hr}\end{array}$ & & & . \\
\hline 1) & Fed (10) & $61 \pm 3$ & $80 \pm 12$ & 1 & $3900 \pm 75$ & $568 \pm 61$ & $36 \pm 2$ & $2.3 \pm 0.2$ & $70 \pm 3$ & Liver preperfused for $15 \mathrm{~min}$ \\
\hline 2) & $\mathrm{CCl}_{4}(4)$ & $69 \pm 4$ & $55 \pm 10$ & 1 & $3700 \pm 80$ & $109 \pm 40$ & $5 \pm 1$ & $2.1 \pm 0.2$ & $63 \pm 3$ & Same \\
\hline 3) & $\begin{array}{l}\mathrm{CCl}_{4}(4) \\
10 \mathrm{~mm} \text { Trp. }\end{array}$ & $43 \pm 2$ & $68 \pm 4$ & 1 & $4100 \pm 110$ & $50 \pm 10$ & $6 \pm 2$ & $1.9 \pm 0.2$ & $59 \pm 6$ & Same \\
\hline 4) & $\begin{array}{l}\mathrm{CCl}_{4}(7) \\
10 \mathrm{~mm} \text { Trp. }\end{array}$ & $62 \pm 2$ & $60 \pm 3$ & 1 & $4400 \pm 90$ & $286 \pm 39$ & $19 \pm 2$ & $2.3 \pm 0.2$ & $66 \pm 1$ & Liver preperfused for $1 \mathrm{hr}$ \\
\hline 5) & $\mathrm{CCl}_{4}(5)$ & $60 \pm 5$ & $58 \pm 9$ & 1 & $4400 \pm 170$ & $186 \pm 26$ & $12 \pm 1$ & $2.3 \pm 0.3$ & $68 \pm 3$ & Same \\
\hline 6) & $\mathrm{CCl}_{4}(4)$ & $49 \pm 4$ & $55 \pm 4$ & 1 & $4560 \pm 180$ & $80 \pm 3$ & $8 \pm 1$ & $2.4 \pm 0.1$ & $72 \pm 7$ & $\begin{array}{l}\text { Same: donor rabbit received cortisone } \\
\text { acetate } 3 \mathrm{mg} / \mathrm{kg}\end{array}$ \\
\hline 7) & $\begin{array}{l}\mathrm{CCl}_{4}(5) \\
10 \mathrm{~mm} \operatorname{Trp} .\end{array}$ & $67 \pm 2$ & $76 \pm 12$ & 1 & $4540 \pm 270$ & $297 \pm 58$ & $20 \pm 4$ & $2.1 \pm 0.3$ & $68 \pm 5$ & $\begin{array}{l}\text { Same: donor rabbit received cortisone } \\
\text { acetate } 3 \mathrm{mg} / \mathrm{kg}\end{array}$ \\
\hline 8) & $\begin{array}{l}\mathrm{CCl}_{4}(4) \\
10 \mathrm{~mm} \text { Trp. }\end{array}$ & $41 \pm 3$ & $75 \pm 6$ & 1 & $3600 \pm 140$ & $43 \pm 9$ & $3 \pm 1$ & $1.4 \pm 0.2$ & $51 \pm 5$ & Same: donor rabbit fasted for $48 \mathrm{hr}$ \\
\hline 9) & $\mathrm{CCl}_{4}(2)$ & $65 ; 51$ & $38 ; 58$ & 1 & $4220 ; 3760$ & $37 ; 134$ & $3 ; 9$ & $2.1 ; 2.5$ & $68 ; 62$ & $\begin{array}{l}\text { Same: donor rabbit treated with DPPD } \\
27 \text { and } 3 \mathrm{hr} \text { before } \mathrm{CCl}_{4}\end{array}$ \\
\hline
\end{tabular}

The numbers noted in the parentheses represent the number of studies.

土, SEM; Trp., tryptophan.

In groups 6 and 7 cortisone acetate was not present in the perfusate albumin synthesis is determined from columns B, D, E, and F. $\mathrm{G}=\mathrm{F} \times \mathrm{E} / \mathrm{D} \times 100 / \mathrm{B}$.

$\min , 40 \pm 2 \%$ at $60 \mathrm{~min}$ and $70 \pm 3 \%$ at $120 \mathrm{~min}$ of perfusion. Thus, the requirement that urea production remain stable was satisfied.

In livers from fed donors that received $\mathrm{CCl}_{4}$ (group 2) albumin synthesis decreased to $5 \mathrm{mg} / 100 \mathrm{~g}$ liver per 2.5 $\mathrm{hr}$ from a control value of $36 \mathrm{mg}$. Enrichment of the perfusate with $10 \mathrm{~mm}$ tryptophan did not augment albumin synthesis (group 3 ) unless the livers were exposed to this level of tryptophan for at least $60 \mathrm{~min}$ before the measurement of albumin synthesis (group 4 ). Preperfusion with a control perfusate before measuring albumin synthesis also resulted in some improvement in albumin synthesis but not to the same degree as when excess tryptophan was present (group 5 vs. group 4 ) : $P$ value less than 0.05).

Because cortisone acetate has been shown to result in reaggregation of the endoplasmic reticulum-bound polysome in the absence of new RNA synthesis, its effect on $\mathrm{CCl}_{4}$ exposed livers was studied. Pretreating the donor with cortisone acetate, $3 \mathrm{mg} / \mathrm{kg}$ body weight $2 \mathrm{hr}$ before $\mathrm{CCl}_{4}$ administration failed to result in any improvement in albumin synthesis (group 6) unless tryptophan was present in the perfusate (group 7).

Starvation has been reported to increase the sensitivity of an animal to the toxic effects of $\mathrm{CCl}_{4}(27)$ and as is seen in the fasted animals (group 8) that despite the presence of tryptophan albumin synthesis was near zero.

Antioxidants have been suggested as preventing the toxic manifestations of the metabolites of $\mathrm{CCl}_{4}$. However, the pretreatment of two donor rabbits with DPPD
27 and $3 \mathrm{hr}$ before $\mathrm{CCl}_{4}$ ingestion failed to prevent the decrease in albumin synthesis (4). There was no decrease in albumin synthesis in control studies with DPPD or with mineral oil and these studies were included in group 1.

Endoplasmic reticulum-bound polysome profiles (Fig. 1) were obtained in the groups studied and were either aggregated as seen in the fed control groups or disaggregated after $\mathrm{CCl}_{4}$. Minimal reaggregation was noted with perfusion for $1 \mathrm{hr}$.

Hepatic RNA/DNA and protein/DNA ratios were 2.0-2.6 and 59-72 in control groups and were not altered by $\mathrm{CCl}_{4}$, tryptophan, or cortisone. In the fasted studies (group 8) there was a significant decrease in both hepatic protein and RNA as was noted previously (13).

Lactate-pyruvate ratios were unaltered by either $\mathrm{CCl}_{4}$, tryptophan, DPPD, or by cortisone. The ratios ranged between 8-20 at the start of perfusion and decreased to values betwen 2-6 at the end of the study. Pyruvate levels were $0.4-0.7 \mu \mathrm{moles} / \mathrm{ml}$ in control perfusions and were not altered in the experimental groups. Oxygen extraction was steady and bile flow ranged between $2-3 \mathrm{ml} / \mathrm{hr}$ in all studies.

\section{DISCUSSION}

The isolated perfused rabbit liver is an effective model for the study of hepatotoxic agents. The donor and the perfusate can be subjected to specific alterations and the effects of varying times of perfusion examined conveniently. 
Employing this model system, the administration of $\mathrm{CCl}$ $2 \mathrm{hr}$ before the measurement of albumin synthesis has been shown to result in a decrease in albumin synthesis of $86 \%$. This loss of hepatic albumin-producing capacity was associated with a marked disaggregation of the endoplasmic membrane-bound polysome (Fig. 1). Smuckler et al. have shown that $\mathrm{CCl}_{4}$ administration results in an alteration in the endoplasmic reticulum and the ribosomes are separated from this structure as well as from mRNA (1-3). No loss of total RNA was noted. These workers also described a decreased incorporation of glycine- ${ }^{12} \mathrm{C}$ into total hepatic and plasma proteins in vivo. Our results are in accord with these findings including the observation that hepatic RNA/DNA and protein/DNA ratios were unaltered by $\mathrm{CCl}_{4}$ ingestion.

Smuckler et al. have demonstrated that the effect of $\mathrm{CCl}_{4}$ or its metabolites altered the interaction between ribosome and mRNA (1-3). Gravela and Dianzani (4) concluded that $\mathrm{CCl}_{4}$ acted by preventing the binding of ribosomes to mRNA after a normal polysomal translation, since $\mathrm{CCl}_{4}$ had no effect when the ribosome was kept bound by the use of cycloheximide. Since both tryptophan (12-14) and cortisone (28) have been shown to favor ribosome mRNA interaction resulting in some degree of reaggregation of the disaggregated-bound polysome, these agents were studied in an attempt to find a means of reducing the toxicity of $\mathrm{CCl}_{4}$. Tryptophan failed to prevent the inhibition of albumin production by $\mathrm{CCl}_{4}$ when the amino acid was given to the donor and when the donated liver was exposed to high concentrations of tryptophan for $15 \mathrm{~min}$. In order to determine if longer perfusions might result in some improvement, perhaps by permitting exchange or removal of some of the toxic metabolites of $\mathrm{CCl}_{4}$, the livers were perfused for $1 \mathrm{hr}$ before the introduction of the label. Some improvement was noted and albumin synthesis rose to about one-third the normal rate. Longer exposure, with $10 \mathrm{~mm}$ tryptophan in the perfusate, did result in more improvement in albumin synthesis indicating that endogenous mRNA and ribosomes can still interact to form albumin. This increased albumin production lends support to the concept that metabolites of $\mathrm{CCl}_{4}$ act either to alter the attachment of ribosomes with mRNA or polysomes with the endoplasmic reticulum; since these interactions are necessary for albumin production.

Employing the isolated liver perfused with $200 \mathrm{mg} / 100$ $\mathrm{ml}$ ethanol, tryptophan has also been shown to exert a protective effect (13). In both of these studies with alcohol and $\mathrm{CCl}_{4}$, significant disaggregation of the endoplasmic membrane-bound polysome occurred and tryptophan resulted in some reaggregation. However the degree of reaggregation could not be related to the increment in albumin synthesis (13), a result not unexpected since
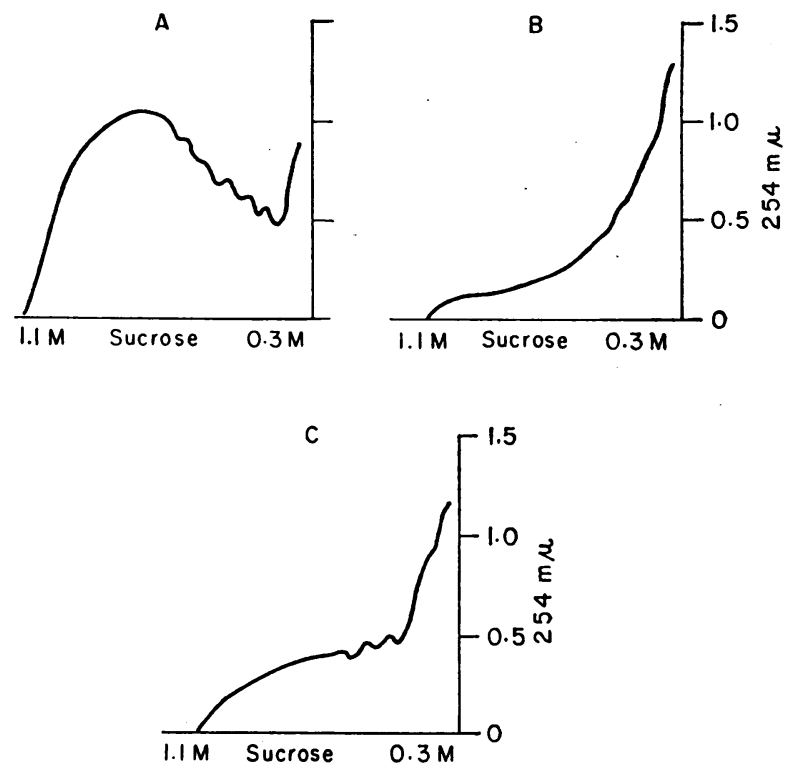

FIGURE 1 Endoplasmic-bound polysome profiles: $(A)$ from fed and fed DPPD-treated donors; $(B) \mathrm{CCl}_{4}$ fed, fasted, or cortisone treated; $(C) \mathrm{CCl}_{4}$ fed donors where livers were preperfused for $1 \mathrm{hr}$ before the addition of $\mathrm{CO}_{2}{ }^{14} \mathrm{C}$. Marked disaggregation occurs with $\mathrm{CCl}_{4}$ and only minimal reaggregation is seen when the liver is perfused for an additional $1 \mathrm{hr}$. The addition of tryptophan does not result in any further increase in aggregation.

the specific polysame for albumin synthesis can not be isolated as yet (Fig. 1).

Cortisone acetate, at a dose of $3 \mathrm{mg} / \mathrm{kg}$ body weight administered $2 \mathrm{hr}$ before the ingestion of $\mathrm{CCl}_{4}$ failed to inhibit the loss of albumin production. To the contrary, there was even a lower value found than with preperfusion alone (groups 5 and $6, P$ less than 0.05 ). This result suggests that this short-term exposure to cortisone may have actually stimulated the microsomal enzyme system responsible for $\mathrm{CCl}_{4}$ metabolism. Thus the toxicity of $\mathrm{CCl}_{4}$ would be enhanced. Cortisone administered to the donor rabbit however failed to alter the response to tryptophan added in excess to the perfusate.

Other factors which have been considered to alter the toxicity of $\mathrm{CCl}_{4}$ are the removal of protein from the diet of rats and the administration of antioxidants. Starvation has been shown to enhance the toxicity of $\mathrm{CCl}_{4}(4,27)$. In four livers from donors, fasted for $48 \mathrm{hr}$, and then treated with $\mathrm{CCl}_{4}$, albumin synthesis was essentially nil and practically no radioactivity was incorporated into albumin. While it is possible that $\mathrm{CCl}_{4}$ was absorbed faster in these animals and the liver exposed to a larger dose, protein synthesis has been shown to be inhibited by a dose as small as $0.5 \mathrm{ml} / \mathrm{kg}$ (1). Tryptophan did not reverse these findings and the total RNA and protein within the hepatic cell remained low (group 8). In two studies the antioxidant, DPPD, failed to augment 
albumin production though no toxic effects of this agent were observed.

Albumin synthesis is extremely sensitive to $\mathrm{CCl}_{4}$ probably secondary to the alterations in the cytoplasmic protein-synthesizing system. Tryptophan has been shown to restimulate albumin synthesis if given shortly after $\mathrm{CCl}_{4}$ ingestion and if present in the perfusate at high levels. While the mechanism of this action of tryptophan is not known it is interesting to speculate that tryptophan aids in the combination of available functionable particles that are still capable of protein synthesis.

\section{ACKNOWLEDGMENTS}

The authors wish to express their appreciation to Mrs. Jean E. Miller for secretarial assistance and to Mr. Alvin Burks and Mr. Joseph Mongelli for technical assistance.

This work was supported in part by U. S. Public Health Service grant AM 02489, and the Licensed Beverage Industries, Inc.

\section{REFERENCES}

1. Smuckler, E. A., and E. P. Benditt. 1965. Studies on carbon tetrachloride intoxication. III. A subcellular defect in protein synthesis. Biochemistry. 4: 671 .

2. Smuckler, E. A., B. Parthier, and T. Hultin. 1968. The effects of polyuridylic acid on phenylalanine incorporation by subcellular fractions from carbon tetrachloride-poisoned rat liver. Biochem. J. 107: 151.

3. Smuckler, E. A., O. A. Iseri, and E. P. Benditt. 1962. An intracellular defect in protein synthesis induced by carbon tetrachloride. J. Exp. Med. 116: 55.

4. Gravela, E., and M. U. Dianzani. 1970. Studies on the mechanism of $\mathrm{CCl}_{4}$-induced polyribosomal damage. $F E$ BS (Fed. Eur. Biochem. Soc.) Lett. 9: 93.

5. Redman, C. M. 1969. Biosynthesis of serum proteins and ferritin by free and attached ribosomes of rat liver. J. Biol. Chem. 244 : 4308.

6. Hicks, S. J., J. W. Drysdale, and H. N. Munro. 1969. Preferential synthesis of ferritin and albumin by different populations of liver polysomes. Science (Wash. D. C.). $164: 584$.

7. Staehelin, T., E. Verney, and H. Sidransky. 1967. The influence of nutritional change on polyribosomes of the liver. Biochim. Biophys. Acta. 145: 105.

8. Baliga, B. S., A. W. Pronczuk, and H. N. Munro. 1968. Regulation of polysome aggregation in a cell-free system through amino acid supply. J. Mol. Biol. 34: 199.

9. Sidransky, H., D. S. R. Sarma, M. Bongiorno, and E. Verney. 1968. Effect of dietary tryptophan on hepatic polyribosomes and protein synthesis in fasted mice. $J$. Biol. Chem. 243: 1123 .

10. Rubin, E., and C. S. Lieber. 1968. Alcohol-induced hepatic injury in nonalcoholic volunteers. $N$. Engl. J. Med. 278: 869.
11. Isselbacher, K. J., and N. J. Greenberger. 1964. Metabolic effects of alcohol on the liver. N. Engl. J. Med. 270: 351, 402.

12. Rothschild, M. A., M. Oratz, J. Mongelli, L. Fishman, and S. S. Schreiber. 1969. Amino acid regulation of albumin synthesis. J. Nutr. 98: 395.

13. Rothschild, M. A., M. Oratz, J. Mongelli, and S. S. Schreiber. 1971. Alcohol-induced depression of albumin synthesis: reversal by tryptophan. J. Clin. Invest. 50: 1812.

14. Rothschild, M. A., M. Oratz, and S. S. Schreiber (Introduction by S. J. Farber). 1972. Effect of tryptophan on the hepatotoxic effects of alcohol and $\mathrm{CCl}_{4}$. Trans. Assoc. Am. Physicians Phila. In press.

15. Rothschild, M. A., M. Oratz, J. Mongelli, and S. S. Schreiber, 1969. Effect of albumin concentration on albumin synthesis in the perfused liver. Am. J. Physiol. 216: 1127

16. Swick, R. W. 1958. Measurement of protein turnover in rat liver. J. Biol. Chem. 231: 751.

17. Reeve, E. B., J. R. Pearson, and D. C. Martz. 1963. Plasma protein synthesis in the liver: method for measurement of albumin formation in vivo. Science (Wash. D.C.). $139: 914$.

18. McFarlane, A. S. 1963. Measurement of synthesis rates of liver produced plasma proteins. Biochem. J. 89: 277.

19. Gornall, A. G., C. J. Bardawill, and M. M. David. 1949. Determination of serum proteins by means of biuret reaction. J. Biol. Chem. 177: 751.

20. Rothschild, M. A., S. S. Schreiber, M. Oratz, and H. L. McGee. 1958. The effects of adrenocortical hormones on albumin metabolism studied with albumin $\mathrm{I}^{131}$. J. Clin. Invest. $37: 1229$.

21. Scheidegger, J. J. 1955. Une micro-méthode de l'immunoélectrophorèse. Int. Arch. Allergy Appl. Immunol. $7: 103$.

22. Conway, E. J., and A. Byrne. 1933. Absorption apparatus for micro-determination of certain volatile substances. I. The micro-determination of ammonia. Biochem. J. 27: 419.

23. Keck, K. 1956. An ultramicro technique for the determination of deoxypentose nucleic acid. Arch. Biochem. Biophys. 63: 446.

24. Fleck, A., and D. Begg. 1965. The estimation of ribonucleic acid using ultraviolet absorption measurements. Biochim. Biophys. Acta. 108: 333.

25. Lowry, O. H., N. J. Rosebrough, A. L. Farr, and R. J. Randall. 1951. Protein measurement with the Folin phenol reagent. J. Biol. Chem. 193: 265.

26. Blobel, G., and R. Van Potter. 1967. Ribosomes in rat liver: an estimate of the percentage of free and membrane-bound ribosomes interacting with messenger RNA IN VIVO. J. Mol. Biol. 28 : 539.

27. McLean, A. E. M. 1967. The effect of diet and vitamin $\mathrm{E}$ on liver injury due to carbon tetrachloride. $\mathrm{Br} . \mathrm{J}$. Exp. Pathol. 48: 632.

28. Enwonwu, C. O., and H. N. Munro. 1971. Changes in liver polyribosome patterns following administration of hydrocortisone and actinomycin D. Biochim. Biophys. Acta. 238 : 264. 